\title{
Characterization of Monilinia spp. Populations on Stone Fruit in South Italy
}

\author{
D. Abate, C. Pastore, D. Gerin, R. M. De Miccolis Angelini, C. Rotolo, S. Pollastro, ${ }^{\dagger}$ and F. Faretra, Department of Soil, Plant and Food \\ Sciences, Università degli Studi di Bari Aldo Moro, 70126 Bari, Italy
}

\begin{abstract}
Monilinia spp. are responsible for brown rot decay of stone and pome fruit in the field as well as in postharvest. Monilinia laxa and M. fructigena are considered indigenous to Europe, while M. fructicola is a quarantine pathogen in the European and Mediterranean Plant Protection Organization area included in the A2 List. In Italy, it was first reported in 2009 in Piedmont (northern Italy) and rapidly spread to central Italy. We carried out a monitoring program on the occurrence of Monilinia spp. in southern Italy and a comparative characterization of the three main fungal pathogens. Molecular assays based on direct polymerase chain reaction (PCR) and real-time quantitative PCR for molecular identification of Monilinia spp. from rotted fruit were set up, validated, and applied in a monitoring program. Of the tested 519 isolates from 26 orchards, $388(74.8 \%)$ were identified as M. fructicola, $118(22.7 \%)$ as M. laxa, $10(1.9 \%)$ as $M$. fructigena, and $3(0.6 \%)$ were $M$. polystroma.

M. fructicola colonies grew faster and had a higher optimal temperature for growth $\left(26^{\circ} \mathrm{C}\right)$ than $M$. laxa $\left(23^{\circ} \mathrm{C}\right)$ and $M$. fructigena $\left(20^{\circ} \mathrm{C}\right)$. No relevant difference in virulence could be observed on artificially inoculated apricot, cherry, and peach fruit. The fungal species showed different responses to fungicides, because $M$. fructicola was more sensitive than $M$. laxa, especially to cyflufenamid, and $M$. fructigena revealed a lower sensitivity to succinate dehydrogenase inhibitors (boscalid, fluopyram, and fluxapyroxad) and quinone outside inhibitors (mandestrobin). In summary, the two species M. fructicola and M. polystroma were first detected in southern Italy where $M$. fructicola has largely displaced the two indigenous pathogens $M$. laxa and $M$. fructigena; the relative proportions of the three pathogens in orchards should be considered when defining the management of brown rot of stone fruit due to differences in their responses to fungicides.
\end{abstract}

Brown rot is an important disease affecting stone and pome fruit in the field as well as in postharvest (Byrde and Willetts 1977). The disease is caused by one or more of six closely related specie of Monilinia: Monilinia fructicola (G. Winter) Honey (Mordue 1979a), M. fructigena Honey (Mordue 1979b), M. laxa (Aderh. \& Ruhland) Honey (Mordue 1979c), M. polystroma (G. Leeuwen) L. M. Kohn (Van Leeuwen et al. 2002), M. mumeicola (Y. Harada, Y. Sasaki \& Sano) Sandoval-Denis \& Crous (Harada et al. 2004), and M. yunnanensis (M. J. Hu \& C. X. Luo) Sandoval-Denis \& Crous (Hu et al. 2011). These species are differently distributed across the world and, to date, they occur all together only in Central and Eastern Asia, the area of origin of Prunus L., Malus Mill., and Pyrus L. trees. M. fructicola (MFRC), M. laxa (MLAX), M. fructigena (MFRG), and the new species $M$. polystroma (MPOL) are the main causal agents of brown rot and each have a different regulatory status depending on regional regulations. MLAX is the most common brown rot pathogen and occurs in many places worldwide (https://www.cabi.org/isc/ datasheet/34749). MFRG is mostly restricted to European countries and parts of Asia but is absent from South America, Australia, and New Zealand (https://www.cabi.org/isc/datasheet/34747). MLAX and MFRG, causing the European brown rot, were the only species present in Europe until the turn of the millennium. MPOL was first described in Japan (Van Leeuwen et al. 2002) and is restricted to such Asiatic and European regions (https://gd.eppo.int/taxon/MONIPO/ distribution), including central Italy (Martini et al. 2014). MFRC is responsible for the American brown rot and originally occurred in

${ }^{\dagger}$ Corresponding author: S. Pollastro; E-mail: stefania.pollastro@uniba.it

Funding: This research was partially carried out in the framework of the projects "Laboratory network for the selection, characterization and conservation of germplasm and for preventing the spread of economically relevant and quarantine pests (SELGE) No. 14", founded by the Apulia Region, PO FESR 2007-2013-Axis I, Line of intervention 1.2., Action 1.2.1; and "Promotion of ECO-friendly processes for the enhancement of quality of apulian food productions" granted by the "Distretto Agroalimentare Regionale-D.A.Re. s.c.ar.l. The funders had no role in study design, data collection and analysis, decision to publish, or preparation of the manuscript.

Accepted for publication 26 February 2018.

() 2018 The American Phytopathological Society
North and South America, Japan, Australia, New Caledonia, and New Zealand but now occurs worldwide (https://www.cabi.org/isc/ datasheet/34746). In Europe, MFRC is recommended for regulation as a quarantine pest by the European and Mediterranean Plant Protection Organization and it is included in the A2 List (https://www.eppo. int/QUARANTINE/listA2.htm). The pathogen was first introduced in 2001 in France (OEPP/EPPO 2002) and, successively, was reported in restricted areas or with sporadic occurrence in Azerbaijan, Croatia, Czech Republic, Germany, Greece, Hungary, Poland, Romania, Serbia, Slovenia, Spain, and Switzerland (Riccioni and Valente 2015) (https://gd.eppo.int/taxon/MONIFC/distribution). In Italy, MFRC was first detected in Piedmont (northern Italy) (Pellegrino et al. 2009) and, successively, it was reported in Emilia-Romagna and Lazio (central Italy) (Martini et al. 2013).

The introduction of MFRC in other Mediterranean countries such as Spain and Greece caused changes in the dynamics of Monilinia indigenous populations because it almost completely displaced MFRG and partially displaced MLAX (Papavasileiou et al. 2015; Villarino et al. 2013). Monilinia spp. cause similar symptoms on fruit and their identification is complicated by the fact that morphological characteristics such as conidial size, hyphae diameter, germ tube formation, and colony color and shape are strongly influenced by experimental conditions. Because accurate identification is crucial for improving disease management, several molecular tools have been developed to facilitate identification of Monilinia spp. (Boehm et al. 2001; Côté et al. 2004; Förster and Adaskaveg 2000; Gell et al. 2007; Guinet et al. 2016; Hughes et al. 2000; Ioos and Frey 2000; Luo et al. 2007; Ma et al. 2003; Riccioni and Valente 2015; Van Brouwershaven et al. 2010; Vilanova et al. 2017; Zhu et al. 2016).

This purpose of this work was to (i) monitor the occurrence and distribution of the Monilinia spp. associated with brown rot on stone fruit in southern Italy, in which new molecular tools for their quantitative detection were set up, validated, and used; and (ii) determine the influence of the effect of temperature on the pathogenicity and response to fungicides of MFRC, MFRG, and MLAX, on apricot, cherry and peach.

\section{Materials and Methods}

Media. The following media were used (ingredients per liter of distilled water; media were added with Oxoid number 3 at $20 \mathrm{~g}$ liter $^{-1}$ agar): water agar (WA), potato dextrose agar (PDA; infusion from $200 \mathrm{~g}$ of peeled and sliced potato kept at $60^{\circ} \mathrm{C}$ for $1 \mathrm{~h}$ and 
$20 \mathrm{~g}$ of dextrose, adjusted to $\mathrm{pH}$ 6.5), potato sucrose agar (PSA; infusion from $200 \mathrm{~g}$ of peeled and sliced potato kept at $100^{\circ} \mathrm{C}$ for $40 \mathrm{~min}$ and $10 \mathrm{~g}$ of sucrose, adjusted to $\mathrm{pH}$ 6.5), malt extract agar (MEA; $20 \mathrm{~g}$ of Oxoid malt extract), salicylhydroxamic acid (SHAM) malt extract agar (MEAS; MEA amended with $0.5 \mathrm{mM}$ SHAM [Sigma-Aldrich, St. Louis], a specific inhibitor of cyanide-resistant alternative respiration enhancing the efficacy of quinone outside inhibitor [QoI] fungicides against members of the family Sclerotiniaceae) (Ishii et al. 2009), and minimal medium with added vitamin solution (MMV; $10 \mathrm{ml}$ of solution A [10 g of $\mathrm{KH}_{2} \mathrm{PO}_{4}$ per $100 \mathrm{ml}$ of water], $10 \mathrm{ml}$ of solution $\mathrm{B}$ [20 $\mathrm{g}$ of $\mathrm{NaNO}_{3}, 5 \mathrm{~g}$ of KCl, $5 \mathrm{~g}$ of $\mathrm{MgSO}_{4} \cdot 7 \mathrm{H}_{2} \mathrm{O}$, and $0.1 \mathrm{~g}$ of $\mathrm{FeSO}_{4}$ per $100 \mathrm{ml}$ of water], $1 \mathrm{ml}$ of micronutrient solution [Sanderson and Srb 1965], $10 \mathrm{~g}$ of glucose, and $1 \mathrm{ml}$ of vitamin stock solution [Beadle and Tatum 1945] sterilized through a $0.22-\mu \mathrm{m}$-pore filter and added to autoclaved media cooled to $50^{\circ} \mathrm{C}$ ).

Monitoring and fungal isolates. Monilinia isolates were collected from rotted apricot, cherry, nectarine, peach, and plum fruit close to ripening; fruit were sampled in 26 orchards located in southern Italy (Table 1) from July to September 2014 and occasionally in the years 2015 to 2016 . Conidia, when present, were collected by scraping the sporulation, suspended in distilled water with $0.01 \%$ of Tween 20 (Sigma-Aldrich), and spread at low density on WA. Single overnight germinated conidia were transferred on PDA and incubated at $21 \pm 0.5^{\circ} \mathrm{C}$ in darkness for 5 days. Otherwise, the isolates were obtained by placing small fragments of surfacedecontaminated rotted fruit tissues on WA and colony purification on PDA. Isolates, stored at $4 \pm 1^{\circ} \mathrm{C}$ on PSA slants, were revitalized just before use and routinely grown on the same medium at $24 \pm$ $0.5^{\circ} \mathrm{C}$ in darkness. Molecular tools and observations of morphological traits, according to the synoptic key for species identification (Lane 2002; OEPP/EPPO 2009), were used to identify Monilinia spp. The strains MFRC534, MFRG510, and MLAX509 were used as references. The isolates used in the different assays are reported in Table 2.

Molecular identification and quantification of Monilinia spp. Genomic DNA was extracted and purified according to De Miccolis Angelini et al. (2010). Briefly, $200 \mathrm{mg}$ of mycelium, collected by scraping 7-day-old colonies grown at $24 \pm 0.5^{\circ} \mathrm{C}$ on cellophane disks overlaid on MEA or $10^{6}$ conidia pelleted by centrifugation at $14,000 \mathrm{rpm}$ for $15 \mathrm{~min}$, was powdered under liquid nitrogen and added to $600 \mu \mathrm{l}$ of cetyltrimethylammonium bromide (CTAB) buffer $(100 \mathrm{mM}$ Tris-Cl, pH 8.0; $1.4 \mathrm{M} \mathrm{NaCl} ; 20 \mathrm{mM}$ EDTA, $\mathrm{pH} 8.0 ; 2 \%$ CTAB [wt/vol]; and $0.2 \% \quad \beta$-mercaptoethanol [vol/vol]). The samples were frozen and thawed three times using liquid nitrogen and a water bath at $75^{\circ} \mathrm{C}$, before shaking $\left(30\right.$ strokes s$\left.{ }^{-1}\right)$ for $5 \mathrm{~min}$ in a Mixer Mill (MM301; Retsch, Haan, Germany) and, finally, incubated at $75^{\circ} \mathrm{C}$ for $1 \mathrm{~h}$. After chloroform extraction, the clear supernatant was transferred to a new tube and precipitated with isopropanol at $-80^{\circ} \mathrm{C}$ for $30 \mathrm{~min}$. The tube was centrifuged at $14,000 \mathrm{rpm}$ for $15 \mathrm{~min}$, and the pellet was washed with cold $70 \%$ ethanol, air dried, and dissolved in Tris-EDTA (10 mM Tris-Cl and $1 \mathrm{mM}$ EDTA, pH 8.0). The solution was treated with DNAasefree pancreatic RNAase (Sigma-Aldrich) at $0.1 \mu \mathrm{g} \mu \mathrm{l}^{-1}$ for $2 \mathrm{~h}$ at $37^{\circ} \mathrm{C}$, precipitated by the addition of $0.6 \mathrm{vol}$ of $5 \mathrm{M}$ ammonium acetate and 2 vol of cold absolute ethanol. The final DNA pellet, washed with $70 \%$ ethanol and air dried, was dissolved in water, quantified using a NanoDrop 2000 spectrophotometer (Thermo Fischer Scientific Inc., Wilmington, DE) or a Qubit 2.0 fluorimeter (Life Technologies Ltd., Paisley, UK) for quantitative polymerase chain reaction (qPCR) assays, and stored at $-80^{\circ} \mathrm{C}$ until use.

Multiplex PCR assays. The multiplex PCR assays were performed using the forward primers MO368-10R, LaxaR-2, and MO368-8R specific for MFRC, MLAX, and MFRG or MPOL, respectively, and the common reverse primer MO368-5 described by Côté et al. (2004) (Table 3). Reaction mixtures (25 $\mu 1)$ consisted of $1 \times$ Green GoTaq Flexi Buffer $\left(\mathrm{Mg}^{2+}\right.$ free), $2 \mathrm{mM} \mathrm{MgCl} 2,75 \mu \mathrm{M}$ each nucleotide (dATP, dGTP, dCTP, and dTTP), $0.5 \mu \mathrm{M}$ each primer, $0.75 \mathrm{U}$ of GoTaq DNA polymerase (all PCR reagents were from Promega Corp., Madison, WI), and $50 \mathrm{ng}$ of template DNA.
Amplifications were carried out in a MyCycler thermal cycler (Bio-Rad Laboratories, Hercules, CA) programmed for $1 \mathrm{~min}$ at $94^{\circ} \mathrm{C}$; followed by 30 cycles of $30 \mathrm{~s}$ at $94^{\circ} \mathrm{C}, 30 \mathrm{~s}$ at $60^{\circ} \mathrm{C}$, and $1.5 \mathrm{~min}$ at $72^{\circ} \mathrm{C}$; and a final extension for $2 \mathrm{~min}$ at $72^{\circ} \mathrm{C}$.

To distinguish between MFRG and MPOL, the primer pair GPlaF/ PlaR, amplifying a fragment of $731 \mathrm{bp}$ in MPOL isolates (Zhu et al. 2016) (Table 3), was used and reaction mixture and PCR parameters were modified by adding $1 \mathrm{U}$ of GoTaq DNA polymerase and $0.2 \mu \mathrm{M}$ each primer to the reaction mixture and programming the thermal cycler for $3 \mathrm{~min}$ at $95^{\circ} \mathrm{C}$, followed by 30 cycles of amplification $\left(30 \mathrm{~s}\right.$ at $95^{\circ} \mathrm{C}, 30 \mathrm{~s}$ at $60^{\circ} \mathrm{C}$, and $1.5 \mathrm{~min}$ at $\left.72^{\circ} \mathrm{C}\right)$, and a final extension of $10 \mathrm{~min}$ at $72^{\circ} \mathrm{C}$.

To improve the multiplex PCR assay for monitoring purposes, a direct PCR using conidia and mycelium collected from rotted fruit or colonies grown on MEA was set up. These were suspended in sterile distilled water and 1- $\mu$ l aliquots of the suspension, containing approximately a few hundred conidia, were directly transferred into the PCR mixture detailed above without DNA polymerase and kept $15 \mathrm{~min}$ at $98^{\circ} \mathrm{C}$. Then, $0.75 \mathrm{U}$ of GoTaq DNA polymerase (Promega Corp.) was added and the PCR was performed using the conditions described above. The method was validated on 253 samples of brown rotted fruit, and results were compared with those obtained by multiplex PCR and morphological identification (Lane 2002).

No-template controls (NTC), in which water replaced the target DNA, were always run. Aliquots $(5 \mu \mathrm{l})$ of each PCR product were separated by electrophoresis on $1.5 \%$ (wt/vol) agarose gels (Certified Molecular Biology Agarose; Bio-Rad Laboratories), added to GelRed (Biotium, Hayward CA) at $0.05 \mu \mathrm{ml} \mathrm{ml}^{-1}$ in $1 \times$ Trisacetate-EDTA buffer $\left(40 \mathrm{mM}\right.$ Tris, $20 \mathrm{mM} \mathrm{CH}_{3} \mathrm{COOH}$, and $1 \mathrm{mM}$ $\mathrm{Na}_{2}$ EDTA; $\mathrm{pH}$ 8.0), and viewed and photographed under UV light into System Gel Doc 1000 (Bio-Rad Laboratories) using Quantity One software, version 4 (Bio-Rad Laboratories).

Table 1. Numbers and location of monitored stone-fruit orchards

\begin{tabular}{|c|c|c|c|}
\hline $\begin{array}{l}\text { Orchard } \\
\text { number }\end{array}$ & Location & Host plant & GPS coordinates \\
\hline \multicolumn{4}{|l|}{ Basilicata } \\
\hline 1 & Lavello & Prunus domestica & $41^{\circ} 02^{\prime} 39^{\prime \prime} \mathrm{N}, 15^{\circ} 48^{\prime} 16^{\prime \prime} \mathrm{E}$ \\
\hline 2 & Lavello & P. platicarpa & $41^{\circ} 03^{\prime} 41^{\prime \prime} \mathrm{N}, 15^{\circ} 46^{\prime} 53^{\prime \prime} \mathrm{E}$ \\
\hline 3 & Metaponto & Persica laevis & $40^{\circ} 22^{\prime} 09^{\prime \prime} \mathrm{N}, 16^{\circ} 46^{\prime} 44^{\prime \prime} \mathrm{E}$ \\
\hline 4 & $\begin{array}{l}\text { Montalbano } \\
\text { Jonico }\end{array}$ & Prunus armeniaca & $40^{\circ} 17^{\prime} 54^{\prime \prime} \mathrm{N}, 16^{\circ} 34^{\prime} 32^{\prime \prime} \mathrm{E}$ \\
\hline 5 & Montemilone & P. persica & $41^{\circ} 02^{\prime} 25^{\prime \prime} \mathrm{N}, 15^{\circ} 58^{\prime} 29^{\prime \prime} \mathrm{E}$ \\
\hline 6 & Policoro & P. platicarpa & $40^{\circ} 12^{\prime} 45^{\prime \prime} \mathrm{N}, 16^{\circ} 41^{\prime} 43^{\prime \prime} \mathrm{E}$ \\
\hline 7 & Tursi & P. platicarpa & $40^{\circ} 15^{\prime} 41^{\prime \prime} \mathrm{N}, 16^{\circ} 27^{\prime} 29^{\prime \prime} \mathrm{E}$ \\
\hline 8 & Tursi & P. domestica & $40^{\circ} 15^{\prime} 34^{\prime \prime} \mathrm{N}, 16^{\circ} 28^{\prime} 08^{\prime \prime} \mathrm{E}$ \\
\hline 9 & Tursi & P. domestica & $40^{\circ} 15^{\prime} 22^{\prime \prime} \mathrm{N}, 16^{\circ} 28^{\prime} 57^{\prime \prime} \mathrm{E}$ \\
\hline 10 & Tursi & P. domestica & $40^{\circ} 13^{\prime} 17^{\prime \prime} \mathrm{N}, 16^{\circ} 27^{\prime} 57^{\prime \prime} \mathrm{E}$ \\
\hline 11 & Tursi & P. persica & $40^{\circ} 13^{\prime} 34^{\prime \prime} \mathrm{N}, 16^{\circ} 30^{\prime} 15^{\prime \prime} \mathrm{E}$ \\
\hline \multicolumn{4}{|l|}{ Campania } \\
\hline 12 & Caserta & P. avium & $41^{\circ} 04^{\prime} 41^{\prime \prime} \mathrm{N}, 14^{\circ} 22^{\prime} 37^{\prime \prime} \mathrm{E}$ \\
\hline \multicolumn{4}{|l|}{ Puglia } \\
\hline 13 & Bisceglie & P. avium & $41^{\circ} 13^{\prime} 36^{\prime \prime} \mathrm{N}, 16^{\circ} 28^{\prime} 15^{\prime \prime} \mathrm{E}$ \\
\hline 14 & Corato & P. avium & $41^{\circ} 10^{\prime} 54^{\prime \prime} \mathrm{N}, 16^{\circ} 28^{\prime} 23^{\prime \prime} \mathrm{E}$ \\
\hline 15 & $\begin{array}{l}\text { Ceglie } \\
\text { Messapica }\end{array}$ & P. domestica & $40^{\circ} 38^{\prime} 32^{\prime \prime} \mathrm{N}, 17^{\circ} 29^{\prime} 06^{\prime \prime} \mathrm{E}$ \\
\hline 16 & Cerignola & P. armeniaca & $41^{\circ} 17^{\prime} 03^{\prime \prime} \mathrm{N}, 15^{\circ} 55^{\prime} 16^{\prime \prime} \mathrm{E}$ \\
\hline 17 & $\begin{array}{l}\text { Gioia del } \\
\text { Colle }\end{array}$ & P. avium & $40^{\circ} 46^{\prime} 60^{\prime \prime} \mathrm{N}, 16^{\circ} 51^{\prime} 30^{\prime \prime} \mathrm{E}$ \\
\hline 18 & $\begin{array}{l}\text { Gioia del } \\
\text { Colle }\end{array}$ & P. avium & $40^{\circ} 47^{\prime} 23^{\prime \prime} \mathrm{N}, 16^{\circ} 57^{\prime} 59^{\prime \prime} \mathrm{E}$ \\
\hline 19 & Loconia & P. persica & $41^{\circ} 09^{\prime} 42^{\prime \prime} \mathrm{N}, 15^{\circ} 56^{\prime} 06^{\prime \prime} \mathrm{E}$ \\
\hline 20 & Noicattaro & Persica laevis & $41^{\circ} 02^{\prime} 22^{\prime \prime} \mathrm{N}, 16^{\circ} 57^{\prime} 54^{\prime \prime} \mathrm{E}$ \\
\hline 21 & Noicattaro & Prunus persica & $41^{\circ} 01^{\prime} 52^{\prime \prime} \mathrm{N}, 17^{\circ} 00^{\prime} 41^{\prime \prime} \mathrm{E}$ \\
\hline 22 & Rutigliano & P. avium & $41^{\circ} 00^{\prime} 20^{\prime \prime} \mathrm{N}, 16^{\circ} 59^{\prime} 49^{\prime \prime} \mathrm{E}$ \\
\hline 23 & Rutigliano & P. persica & $40^{\circ} 59^{\prime} 31^{\prime \prime} \mathrm{N}, 17^{\circ} 01^{\prime} 48^{\prime \prime} \mathrm{E}$ \\
\hline 24 & $\begin{array}{l}\text { Sammichele di } \\
\text { Bari }\end{array}$ & P. armeniaca & $40^{\circ} 52^{\prime} 37^{\prime \prime} \mathrm{N}, 16^{\circ} 55^{\prime} 08^{\prime \prime} \mathrm{E}$ \\
\hline 25 & Turi & P. avium & $40^{\circ} 54^{\prime} 28^{\prime \prime} \mathrm{N}, 16^{\circ} 59^{\prime} 23^{\prime \prime} \mathrm{E}$ \\
\hline 26 & Turi & Persica laevis & $40^{\circ} 53^{\prime} 57^{\prime \prime} \mathrm{N}, 17^{\circ} 03^{\prime} 39^{\prime \prime} \mathrm{E}$ \\
\hline
\end{tabular}


qPCR assays. A real-time qPCR to detect and quantify each of the three species MFRC, MFRG, and MLAX was set up and validated according to Bustin et al. (2009). We used sequences of amplicons obtained using single primer pairs by Côté et al. (2004) and DNA from eight isolates of MFRC, two of MLAX, and six of MFRG. The reaction mixture $(50 \mu \mathrm{l})$ contained $1 \times$ LA PCR Buffer II $\left(\mathrm{Mg}^{2+}\right.$ free), $1.5 \mathrm{mM} \mathrm{MgCl}, 0.2 \mathrm{mM}$ each dNTP, $2 \mathrm{U}$ of TaKaRa LATaq DNA polymerase (all reagents were from Takara Bio Inc., Otsu, Shiga, Japan), $0.1 \mu \mathrm{M}$ each primer, and $100 \mathrm{ng}$ of template DNA. PCR amplifications were performed using the following conditions: $5 \mathrm{~min}$ at $95^{\circ} \mathrm{C} ; 30$ cycles of $1 \mathrm{~min}$ at $95^{\circ} \mathrm{C}, 1 \mathrm{~min}$ at $60^{\circ} \mathrm{C}$, and $1 \mathrm{~min}$ at $72^{\circ} \mathrm{C}$; followed by a final extension of $7 \mathrm{~min}$ at $72^{\circ} \mathrm{C}$. PCR products were subjected to Sanger sequencing in both forward and reverse directions using the same primers as for PCR by an external service (Macrogen Europe, Amsterdam, The Netherlands). BLAST tools (https://www.ncbi.nlm.nih.gov/) and SeqMan Pro of the Lasergene software package (v.10.1; DNASTAR, Inc., Madison, WI) were used to align and analyze sequences, including reference sequences of MFRC DAOM 144721 (accession number AF506700), MLAX LMK 656 (accession number AF506702), and MFRG ATCC11790 (accession number AF506701).

Primer pairs and probes were designed using the option TaqMan Quantification of the Primer Express 3.0 software (Applied Biosystems, Foster City, CA) on a consensus DNA region conserved in each species but polymorphic in the others. The species-specific primer pairs and probes (Table 3) were synthesized by Macrogen (Macrogen Inc., Seoul, Korea). qPCR and multiplex qPCR experiment set ups and data analysis were performed in a CFX96 real-time PCR detection system thermal cycler with CFX Manager software (version 3.1; Bio-Rad Laboratories). The amplification mixture $(12.5 \mu \mathrm{l})$ consisted of $1 \times$ SsoAdvanced Universal Probes Supermix (Bio-Rad Laboratories), $240 \mathrm{nM}$ each primer, $160 \mathrm{nM}$ each probe, and $50 \mathrm{ng}$ of DNA template. Thermal cycling was performed at $95^{\circ} \mathrm{C}$ for $3 \mathrm{~min}$, followed by 30 cycles of $95^{\circ} \mathrm{C}$ for $10 \mathrm{~s}$ and $64^{\circ} \mathrm{C}$ for $30 \mathrm{~s}$. All qPCR

Table 2. Origin of Monilinia spp. isolates used in the different assays

\begin{tabular}{|c|c|c|c|}
\hline Isolates & Location & Host plant & Year \\
\hline \multicolumn{4}{|l|}{ Monilinia fructicola } \\
\hline Mfrc69y, Mfrc77y, Mfrc78wy, Mfrc88y, Mfrc93 & Caserta (Campania, Italy) & Prunus avium & 2014 \\
\hline Mfrc106y, Mfrc111'y, Mfrc123wx, Mfrc144y & Bisceglie (Puglia, Italy) & P. avium & 2014 \\
\hline Mfrc $150^{\text {wxy }}$ & Tursi (Basilicata, Italy) & P. domestica & 2014 \\
\hline Mfrc261 wx & Policoro (Basilicata, Italy) & P. platicarpa & 2014 \\
\hline Mfrc $301^{w}$ & Gioia del Colle (Puglia, Italy) & P. avium & 2014 \\
\hline Mfrc534yz & United States & P. armeniaca & Unknown \\
\hline \multicolumn{4}{|l|}{ M. fructigena } \\
\hline Mfrg269wxy Mfrg340wy, Mfrg341 & Tursi (Basilicata, Italy) & P. domestica & 2014 \\
\hline Mfrg342 wxy, Mfrg343wy & Lavello (Basilicata, Italy) & P. persica & 2014 \\
\hline Mfrg344xyz & Emilia Romagna (Italy) & Pyrus communis & Unknown \\
\hline Mfrg345wz & Emilia Romagna (Italy) & Malus domestica & Unknown \\
\hline Mfrg510wyz & Utrecht (CBS 101 501) & Prunus persica & 1996 \\
\hline \multicolumn{4}{|l|}{ M. laxa } \\
\hline Mlax34w & Valenzano (Puglia, Italy) & P. dulcis & 1994 \\
\hline Mlax302wxy, Mlax309y, Mlax316 wxy & Gioia del Colle (Puglia, Italy) & P. avium & 2014 \\
\hline Mlax $346^{\mathrm{wx}}$ & Lavello (Basilicata, Italy) & P. armeniaca & 2014 \\
\hline Mlax509wyz & Italia (CBS 101 503) & P. persica & 1992 \\
\hline
\end{tabular}

Table 3. Primers and probes used in polymerase chain reaction (PCR) and quantitative (q)PCR assays

\begin{tabular}{|c|c|c|c|}
\hline Assay, species $^{\mathbf{z}}$ & Primer, probe & Sequences $\left(5^{\prime}-3^{\prime}\right)$ & Amplicon size (bp) \\
\hline \multicolumn{4}{|l|}{ Multiplex PCR } \\
\hline \multirow[t]{2}{*}{ M. laxa } & Laxa-R2-Fw & TGCACATCATATCCCTCGAC & 351 \\
\hline & MO368-5-Rev & GCAAGGTGTCAAAACTTCCA & $\ldots$ \\
\hline \multirow[t]{2}{*}{ M. fructicola } & MO368-10R-Fw & AAGATTGTCACCATGGTTGA & 535 \\
\hline & MO368-5-Rev & GCAAGGTGTCAAAACTTCCA & $\ldots$ \\
\hline M. fructigena & MO368-8R-Fw & AGATCAAACATCGTCCATCT & 402 \\
\hline M. polystroma & MO368-5-Rev & GCAAGGTGTCAAAACTTCCA & 425 \\
\hline \multicolumn{4}{|l|}{ PCR } \\
\hline \multirow[t]{2}{*}{ M. polystroma } & GPlaF-Fw & ССАСТТССААСАТСАСТС & 731 \\
\hline & PlaR-Rev & CCCAGATTTCAAAAGCGGATTC & $\ldots$ \\
\hline \multicolumn{4}{|l|}{$\mathrm{qPCR}$} \\
\hline \multirow[t]{3}{*}{ M. fructicola } & Mfrc-Fw & GAATGTCGTGAAAGGATAATGGAA & 79 \\
\hline & Mfrc-Rev & GCTCTTCTCTCСССТTTCTTTACC & $\ldots$ \\
\hline & Mfrc-Probe & FAM-TACTAGAGAGGTCTACGGGTG-BHQ1 & $\ldots$ \\
\hline \multirow[t]{3}{*}{ M. laxa } & Mlax-Fw & GCCAAGGGCTCCGTAGGTA & 65 \\
\hline & Mlax-Rev & CCTTCACGATCTGCCCCTAGT & $\ldots$ \\
\hline & Mlax-Probe & HEX-CGGCAATAGGCACTACG-BHQ1 & $\ldots$ \\
\hline \multirow[t]{3}{*}{ M. fructigena } & Mfrg-Fw & CСТTAAACTTTCTCAACCGCTTTT & 82 \\
\hline & Mfrg-Rev & TGAAGGAAGAATGCAAGTGCTAGA & $\ldots$ \\
\hline & Mfrg-Probe & FAM-ССССТTTCTTTACCCAGACACCACCTCC-BHQ1 & $\ldots$ \\
\hline
\end{tabular}

${ }^{\mathrm{z}}$ Sources: Multiplex PCR (Côté et al. 2004), PCR (Zhu et al. 2016), and qPCR (this study). 
assays were run with appropriate controls, including NTC, to detect potential contaminations. All samples were replicated twice.

The specificity of the qPCR assay was assessed using genomic DNA from a panel of microorganisms commonly associated with stone fruit: Alternaria sp., Aspergillus niger, Botryosphaeria sp., Botrytis cinerea, Cladosporium sp., Colletotrichum sp., Chondrostereum purpureum, Cylindrocarpon sp., Fusarium sp., Mucor sp., Penicillium rubens, P. expansum, Pestalotia sp., Phaeoacremonium sp., Phomopsis amygdali, Sclerotinia sclerotiorum, Trichoderma sp., Verticillium dahliae, and Wilsonomyces carpophilus. The calibration curves for the DNA quantification were generated by plotting the quantification cycle $(\mathrm{Cq})$ values versus the $\log _{10}$ DNA quantity from eight dilutions, ranging from $50 \mathrm{ng}$ to $1 \mathrm{pg}$ of DNA, of each of three isolates for each of the three Monilinia spp. (Mfrc534, Mfrc78, and Mfrc150 for MFRC; Mfrg510, Mfrg342, and Mfrg344 for MFRG; and Mlax509, Mlax316, and Mlax302 for MLAX). Two replicates of each dilution were analyzed. The Cq values, efficiency $(E)$, coefficients of correlation $\left(R^{2}\right)$, and slope were calculated using CFX Manager software (version 3.1; Bio-Rad Laboratories).

The technique was validated on DNA extracted as above from mixtures of conidia of MFRC (isolate Mfrc123) and MLAX (isolate Mlax316) in different ratios (100:0, 90:10, 50:50, 10:90, and 0:100), as well as on 50 field samples.

Response to temperature. The effect of temperature on colony growth of five isolates of each tested Monilinia sp. (Table 2) was evaluated in an in vitro colony-growth test. Mycelial plugs (4 $\mathrm{mm}$ in diameter), excised from the margin of actively growing cultures (7 days old) on MEA, were transferred to fresh MEA and incubated at seven different temperatures $(14,17,20,23,26,29$, and $\left.32 \pm 0.5^{\circ} \mathrm{C}\right)$ in darkness. The orthogonal diameters were measured at 2-day intervals and the average daily growth (in millimeters) was calculated. After 8 days, three mycelial plugs ( $10 \mathrm{~mm}$ in diameter) were excised from the inner, middle, and outer regions of each colony; transferred to a $15-\mathrm{ml}$ tube with added sterile water containing $0.01 \%$ Tween 20 ( $1 \mathrm{ml})$; and vortexed for $1 \mathrm{~min}$. The conidia were counted in a Thoma cell counting chamber. Three replicate colonies were used per isolate and the assay was repeated twice.

Pathogenicity assay. The pathogenicity of three isolates of each species (Table 2) was evaluated by artificial inoculation on fresh ripe Ferrovia cherry, Marietta apricot, and Royal Time peach, previously decontaminated by immersion in $2 \%$ sodium hypochlorite for 3 min, washed twice with sterilized distilled water, and dried at room temperature. The fruit were inoculated with a mycelium plug (2 to $4 \mathrm{~mm}$ in diameter) excised from the margin of 7-day-old cultures on MEA and placed on a wound ( 2 to $4 \mathrm{~mm}$ in diameter by 2 to $3 \mathrm{~mm}$ deep, depending on the fruit) made on the surface of fruit with the help of a sterile corkborer. Fruit inoculated with plugs of sterile MEA were used as control. Fruit, placed in a humid chamber, were incubated at $24 \pm 0.5^{\circ} \mathrm{C}$ in darkness. The orthogonal diameters (in millimeters) of rotted areas were measured at 2-day intervals. Each combination was replicated 10 times and the assay was repeated twice.

Fungicide sensitivity tests. Commercial formulations of the QoI pyraclostrobin (Insignia, 20\% active substance [a.s.]; BASF AG, Limburgerhof, Germany) and mandestrobin (S-2200, 25\% a.s.; Sumitomo Chemical, Tokyo), the succinate dehydrogenase inhibitors (SDHI) fluopyram (Luna Privilege, 50\% a.s.; Bayer CropScience, Leverkusen, Germany) and fluxapyroxad (BAS700, $80 \%$ a.s.; BASF AG), the sterol biosynthesis inhibitors (SBI) class III (SBI-III) fenhexamid (Teldor Plus, 50\% a.s.; Bayer CropScience) and fenpyrazamine (Prolectus, $50 \%$ a.s.; Sumitomo Chemical), and the SBI class I (SBI-I) tebuconazole (Folicur WG, 25\% a.s.; Bayer CropScience;) and cyflufenamid (Takumi SC, $10 \%$ a.s.; Certis Europe, B.V., Saronno [VA], Italy) were suspended in sterile distilled water. Technical-grade SDHI boscalid (Sigma-Aldrich), the anilinopyrimidines (AP) cyprodinil (Syngenta Crop Protection, Münchwilen, Switzerland) and pyrimethanil (BASF AG), and the phenylpyrrole (PP) fludioxonil (Syngenta Crop Protection) were dissolved in dimethylsulfoxide. The final concentration of the solvent was the same in all media, control included, and never exceeded $1 \mathrm{ml} \mathrm{liter}^{-1}$. MEA were used for SBI, SDHI, fludioxonil, and cyflufenamid; MM for AP; and both MEA and MEAS for QoI.

Colony growth assays. Response of Monilinia spp. to different fungicides was evaluated in colony growth assays. Three replicated Petri dishes $(55 \mathrm{~mm}$ in diameter) containing a suitable medium or amended with seven increasing concentrations of each fungicide $\left(0.01,0.03,0.1,0.3,1,3\right.$, and $\left.10 \mathrm{mg} \mathrm{liter}^{-1}\right)$ were inoculated with 4-mm-diameter mycelial plugs from actively growing colonies. The orthogonal diameters of developing colonies were measured at 2-day intervals until 8 to 10 days of incubation at $24 \pm 0.5^{\circ} \mathrm{C}$ in darkness. The percent reduction of colony growth as compared with the control medium was measured. Five isolates of each of the three Monilinia spp. were used (Table 2).

Statistical analyses. All data were analyzed by analysis of variance followed by Tukey's honestly significant different test using CoStat software (CoHort Software, Monterey, CA) at the significance levels $P \leq 0.05$ and $P \leq 0.01$.

\section{Results}

Species monitoring. In all, 519 isolates from 26 orchards were collected and identified at the species level by multiplex PCR and marcomorphological characteristics such as colony color; growth rate; and concentric rings of spore production, lobed colony margin, rosettes, and black arcs associated with rosettes. MFRC, MLAX, and MFRG were clearly distinguished in multiplex PCR (Fig. 1). For three isolates, amplicons were slightly larger in size than that of MFRG. They were identified as MPOL with species-specific PCR primers which yielded the expected 731-bp amplicon (Zhu et al. 2016) (Fig. 1). Both multiplex and direct multiplex PCR from
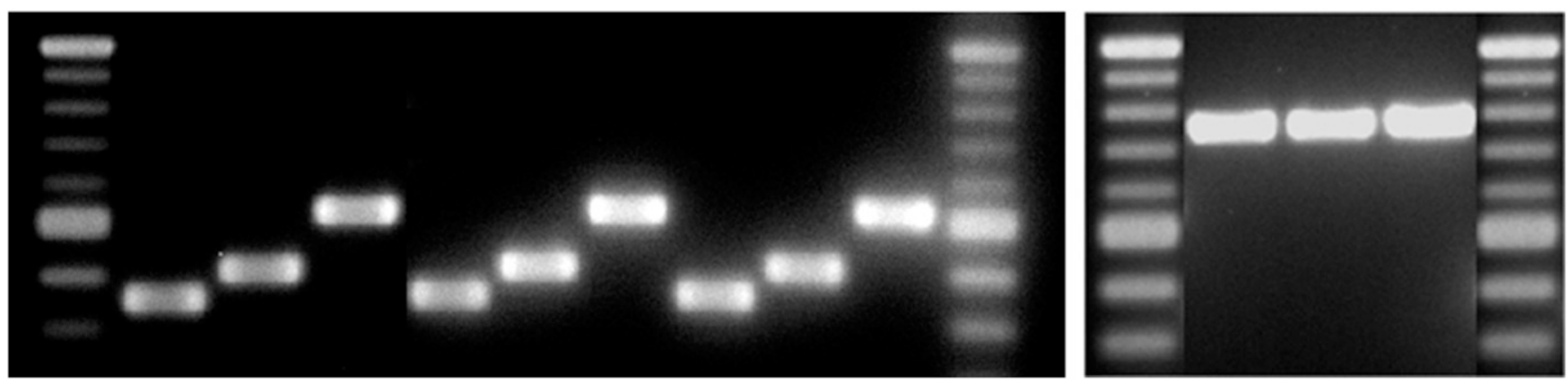

Fig. 1. Examples of multiplex polymerase chain reaction (PCR) performed on the isolates Mlax509 (lanes 2, 5, and 8; 351-bp amplicon), Mfrg510 (lanes 3, 6, and 9; 402-bp amplicon), and Mfrc534 (lanes 4, 7, and 10; 535-bp amplicon). On the left, DNA extracted with cetyldimethylethylammonium bromide buffer from mycelium (lanes 2 to 4) or conidia from rotted fruit (lanes 8 to 10) and direct multiplex PCR from mycelium and conidia from rotted fruit (lanes 11 to 13) are compared. On the right, three isolates (Mpol431, Mpol432, and Mpol433) yielding an amplicon (425 bp) similar to Monilinia fructigena were identified as M. polystroma by PCR with species-specific primers (lanes 13, 14, and 15; 731-bp amplicon). Lanes 1, 11, 12, and 16: 100-bp marker. 
conidia and mycelium from rotted fruit were used to identify 253 of 519 samples with consistent results.

Four Monilinia spp. were found: MFRC was detected in 388 (74.8\%) samples, MLAX in 118 (22.7\%), MFRG in 10 (1.9\%), and MPOL in $3(0.6 \%)$ (Table 4$)$. MFRC was found in 21 of the monitored orchards: 9 in the Basilicata region (191 isolates), 1 in Campania (40 isolates), and 11 in Puglia (157 isolates). MLAX was recovered in 5 orchards in Basilicata (29 isolates) and 10 in Puglia (89 isolates); MFRG was sampled in only 2 orchards in Basilicata (10 isolates); and the three MPOL isolates were found in a single plum orchard in Basilicata. Only a single Monilinia sp. was detected in 14 orchards whereas, in the others, at least two species were detected, generally MFRC and MLAX, but never in coinfection on a same fruit (Table 4).

qPCR assay. Species-specific primers and probes for MFRC, MFRG, and MLAX were designed on the consensus sequences of the amplification products obtained using the primer pairs by Côté et al. (2004) and fungal DNA sequences available at the National Center for Biotechnology Information GenBank database (Table 3). NTC and all nontarget organisms, including the closely related species $B$. cinerea and $S$. sclerotiorum, as well as 17 other fungal species (frequently members of the microbiome of stone and pome fruit or causal agents of wood decay or fruit rots), did not yield any amplification product.

The analytical sensitivity was assessed by testing a range of concentrations of pathogen DNA from $50 \mathrm{ng}$ to $1 \mathrm{pg}$. The limit of detection (LOD) was $0.1 \mathrm{ng}$, with Cq variation of 24.5 to 25.4 for MFRC, 23.8 to 27.8 for MLAX, and 23.1 to 25.0 for MFRG. $E$ and $R^{2}$ values of the qPCR assays and the corresponding calibration curves are reported in Figure 2. The regression between $\log _{10}$ DNA quantities and $\mathrm{Cq}$ values was always linear from 50 to $0.1 \mathrm{ng}$. The same LOD, $E$, and $R^{2}$ values were estimated in multiplex qPCR assays using MFRC- and MLAX-specific primers and probes.
The qPCR protocol was validated for qualitative species identification in amplification of DNA (100 to $400 \mathrm{ng}$ containing 10 to $40 \mathrm{ng}$ of fungal DNA) extracted from 50 field samples and yielded results always in agreement with isolation in agar media (data not shown). Multiplex qPCR was tested for the quantification of both MFRC and MLAX on DNA extracted from mixtures of conidial suspensions in different ratios (MFRC/MLAX $=100: 0$, 90:10, 50:50, 10:90, and 0:100). The assay provided reliable estimates of the relative proportions of conidia in each mixture (Table 5).

Response to temperature. MFRC, MFRG, and MLAX were compared for colony growth at temperatures from 14 to $32^{\circ} \mathrm{C}$ in two replicated experiments (Figs. 3 and 4). MFRC generally grew faster (up to $3 \mathrm{~mm} \mathrm{day}^{-1}$ ) than MLAX and MFRG, particularly at 17 to $26^{\circ} \mathrm{C}$, whereas no significant differences were observed at $32^{\circ} \mathrm{C}$ and, at $14^{\circ} \mathrm{C}$, MFRG grew more slowly than MFRC and MLAX. The optimum temperatures for colony growth were 20,23 , and $26^{\circ} \mathrm{C}$ for MFRG, MLAX, and MFRC, respectively. The optimum temperature for sporulation was $17^{\circ} \mathrm{C}$ for all three species but conidia were much more abundant in MFRC $\left(5 \times 10^{5}\right.$ conidia $\mathrm{cm}^{-2}$ of colony surface $)$ than in MLAX and MFRG $\left(4 \times 10^{3}\right.$ conidia $\left.\mathrm{cm}^{-2}\right)$.

Pathogenicity test. MFRC, MFRG, and MLAX were compared for their pathogenicity on apricot, cherry, and peach fruit. In two replicated experiments, MFRC caused lesions on apricot, cherry, and peach fruit more slowly than MLAX and MFRG, although differences among the species were significant only on apricot (Table 6).

Fungicide sensitivity tests. The sensitivity to the QoI mandestrobin and pyraclostrobin was evaluated on MEA and MEAS, with the latter consisting of MEA amended with SHAM, an inhibitor of alternative oxidases enhancing the activity of QoI fungicides (Ishii et al. 2009). The synergistic effects of QoI and SHAM was confirmed for all three species and both chemicals. MLAX was the most sensitive to both mandestrobin and pyraclostrobin (50\% effective concentration

Table 4. Results of the monitoring of populations of Monilinia spp. sampled in southern Italy

\begin{tabular}{|c|c|c|c|c|c|c|}
\hline \multirow[b]{2}{*}{ Location } & \multirow[b]{2}{*}{ Host plant } & \multicolumn{5}{|c|}{ Number of samples ${ }^{\mathrm{z}}$} \\
\hline & & Total & MLAX & MFRG & MFRC & MPOL \\
\hline \multicolumn{7}{|l|}{ Basilicata } \\
\hline Lavello & Prunus domestica & 14 & 11 & 0 & 3 & 0 \\
\hline Lavello & P. platicarpa & 6 & 2 & 4 & 0 & 0 \\
\hline Metaponto & Persica laevis & 18 & 0 & 0 & 18 & 0 \\
\hline Montalbano Jonico & Prunus armeniaca & 6 & 3 & 0 & 3 & 0 \\
\hline Montemilone & Prunus persica & 8 & 8 & 0 & 0 & 0 \\
\hline Policoro & P. platicarpa & 28 & 0 & 0 & 28 & 0 \\
\hline Tursi & P. platicarpa & 27 & 0 & 0 & 27 & 0 \\
\hline Tursi & P. domestica & 20 & 5 & 6 & 9 & 0 \\
\hline Tursi & P. domestica & 43 & 0 & 0 & 40 & 3 \\
\hline Tursi & P. domestica & 40 & 0 & 0 & 40 & 0 \\
\hline Tursi & P. persica & 23 & 0 & 0 & 23 & 0 \\
\hline \multicolumn{7}{|l|}{ Campania } \\
\hline Caserta & Prunus avium & 40 & 0 & 0 & 40 & 0 \\
\hline \multicolumn{7}{|l|}{ Puglia } \\
\hline Bisceglie & P. avium & 40 & 0 & 0 & 40 & 0 \\
\hline Corato & P. avium & 1 & 1 & 0 & 0 & 0 \\
\hline Ceglie Messapica & P. domestica & 5 & 1 & 0 & 4 & 0 \\
\hline Cerignola & P. armeniaca & 1 & 0 & 0 & 1 & 0 \\
\hline Gioia del Colle & P. avium & 24 & 24 & 0 & 0 & 0 \\
\hline Gioia del Colle & P. avium & 22 & 6 & 0 & 16 & 0 \\
\hline Loconia & P. persica & 2 & 0 & 0 & 2 & 0 \\
\hline Noicattaro & Persica laevis & 6 & 1 & 0 & 5 & 0 \\
\hline Noicattaro & P. persica & 22 & 18 & 0 & 4 & 0 \\
\hline Rutigliano & P. avium & 53 & 13 & 0 & 40 & 0 \\
\hline Rutigliano & P. persica & 16 & 6 & 0 & 10 & 0 \\
\hline Sammichele di Bari & P. armeniaca & 2 & 2 & 0 & 0 & 0 \\
\hline Turi & P. avium & 35 & 17 & 0 & 18 & 0 \\
\hline Turi & Persica laevis & 17 & 0 & 0 & 17 & 0 \\
\hline Total & $\ldots$ & 519 & 118 & 10 & 388 & 3 \\
\hline
\end{tabular}

${ }^{\mathrm{z}} \mathrm{MLAX}=$ Monilinia laxa, $\mathrm{MFRG}=M$. fructigena, $\mathrm{MFRC}=M$. fructicola, and $\mathrm{MPOL}=M$. polystroma. 
[EC ${ }_{50}$ ] of approximately 0.03 and $0.1 \mathrm{mg} \mathrm{liter}^{-1}$, respectively) (Fig. $5)$. The activity of the SDHI boscalid, fluopyram, and fluxapyroxad was evaluated on MEA, and MFRC and MLAX were more sensitive than MFRG to SDHI; their $\mathrm{EC}_{50}$ ranged between 1 and $3 \mathrm{mg} \mathrm{liter}^{-1}$ (Fig. 5). The SBI-III fungicides fenpyrazamine and fenhexamid reduced the colony growth of all three species; generally, fenpyrazamine $\left(\mathrm{EC}_{50}=0.1 \mathrm{mg}\right.$ liter $^{-1}$ for MFRC and MLAX and 0.3 to $1 \mathrm{mg} \mathrm{liter}{ }^{-1}$ for MFRG) was more effective than fenhexamid $\left(\mathrm{EC}_{50}=\right.$ 0.3 to $1 \mathrm{mg} \mathrm{liter}^{-1}$ for MFRC and MFRG and 0.1 to $0.3 \mathrm{mg} \mathrm{liter}^{-1}$ for MLAX). Minimum inhibitory concentration (MIC) ranged from $1 \mathrm{mg} \mathrm{liter}^{-1}$ (MLAX) to $10 \mathrm{mg}$ liter $^{-1}$ (MFRC). The demethylation inhibitor tebuconazole was more effective against MLAX $\left(\mathrm{EC}_{50}=0.01\right.$ to $\left.0.03 \mathrm{mg} \mathrm{liter}{ }^{-1}\right)$ than against MFRG $\left(\mathrm{EC}_{50}=0.03\right.$
Table 5. Validation of quantitative polymerase chain reaction on DNA obtained by mixtures of Monilinia fructicola (MFRC) and M. laxa (MLAX) conidia in different proportions

\begin{tabular}{lcc}
\hline & \multicolumn{2}{c}{ Estimated conidia $(\%)$ means $\pm \mathbf{S E}^{\mathbf{y}}$} \\
\cline { 2 - 3 } MFRC/MLAX $(\boldsymbol{\%})^{\mathbf{z}}$ & MFRC & MLAX \\
\hline $100: 0$ & $100 \pm 0$ & $0 \pm 0$ \\
$90: 10$ & $95.5 \pm 0.7$ & $4.5 \pm 0.7$ \\
$50: 50$ & $50.0 \pm 0.6$ & $50.0 \pm 0.6$ \\
$10: 90$ & $11.4 \pm 1.0$ & $88.6 \pm 1.0$ \\
$0: 100$ & $0 \pm 0$ & $100 \pm 0$ \\
\hline
\end{tabular}

${ }^{\mathrm{y}} \mathrm{SE}=$ Standard error.

${ }^{\mathrm{z}}$ Conidia ratio in the mixture.
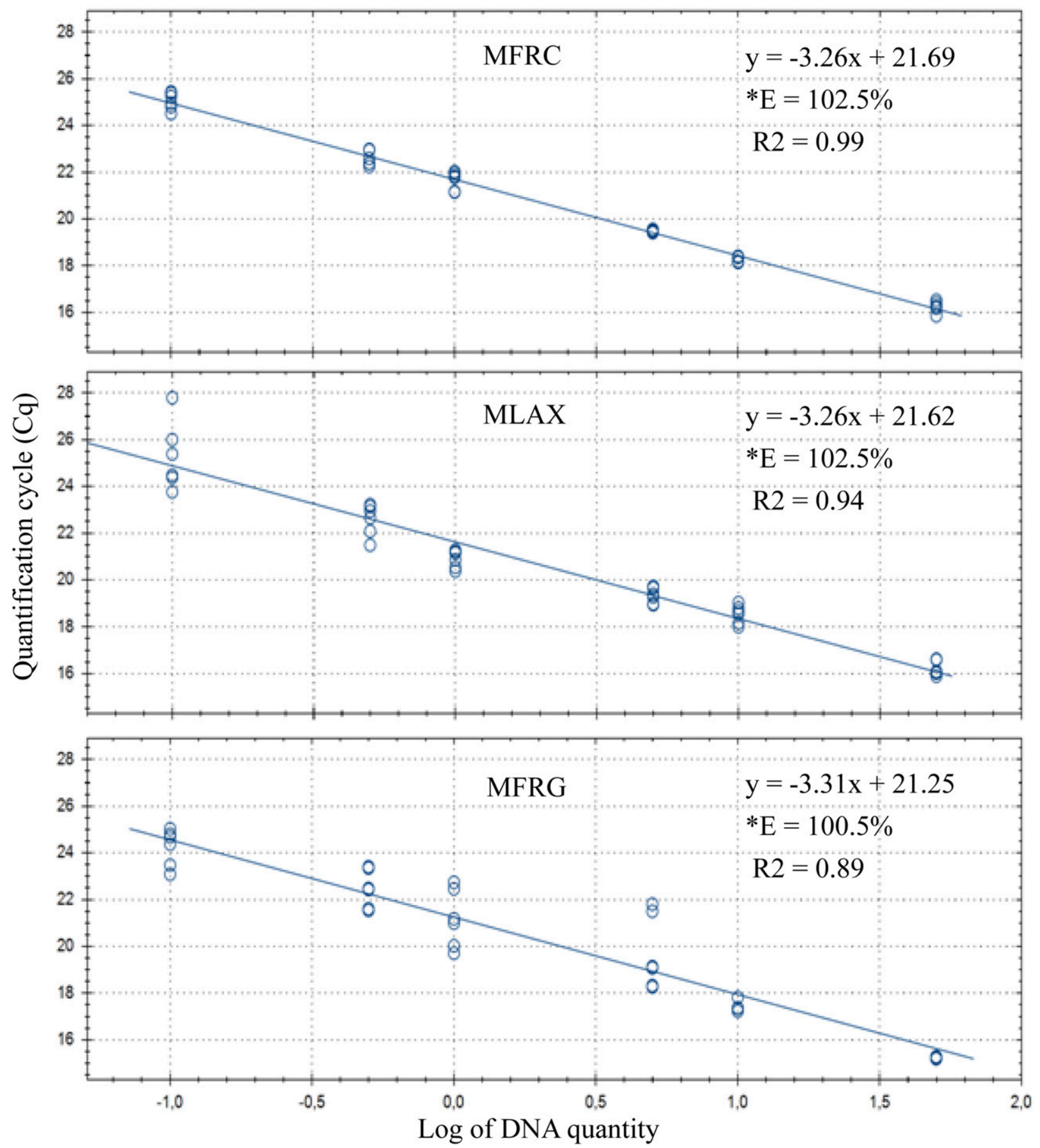

Fig. 2. Calibration curves of quantitative polymerase chain reaction (PCR) assays for Monilinia fructicola (MFRC), M. laxa (MLAX), and M. fructigena (MFRG) determined on three biological replicates (isolates) per species. $\mathrm{E}=\mathrm{PCR}$ efficiency $(\%)$ and $R^{2}=$ correlation coefficient. 
to $0.1 \mathrm{mg} \mathrm{liter}{ }^{-1}$ ) and MFRC ( 0.1 to $0.3 \mathrm{mg} \mathrm{liter}^{-1}$ ). All species were sensitive to the AP cyprodinil and pyrimethanil on MMV, and MLAX and MFRG ( $\mathrm{EC}_{50}=0.01$ to 0.03 and 0.1 to $0.3 \mathrm{mg} \mathrm{liter}^{-1}$, respectively) were slightly more sensitive than $\operatorname{MFRC}\left(\mathrm{EC}_{50}=0.1\right.$ to 0.3 and 0.3 to $1 \mathrm{mg}$ liter $^{-1}$, respectively). The growth of the isolate Mfrg344 was not inhibited even at $10 \mathrm{mg} \mathrm{liter}^{-1}$ and, hence, it was believed to be resistant to AP. Fludioxonil was the most effective fungicide against all the three species $\left(\mathrm{EC}_{50}=0.01\right.$ to $\left.0.03 \mathrm{mg} \mathrm{liter}^{-1} ; \mathrm{MIC}=1 \mathrm{mg} \mathrm{liter}^{-1}\right)$. The three species showed different responses to cyflufenamid: MFRC was the most sensitive $\left(\mathrm{EC}_{50}=0.1\right.$ to $\left.0.3 \mathrm{mg} \mathrm{liter}^{-1}\right)$, followed by MFRG and MLAX, which showed a very poor inhibition $\left(\mathrm{EC}_{50}>\right.$ $10 \mathrm{mg} \mathrm{liter}^{-1}$ ) (Fig. 5).

\section{Discussion}

Brown rot is a severe disease of pome and stone fruit, causing heavy yield losses. At least six Monilinia spp. are identified as causal agents and their populations often coexist in sympatry in the same geographical areas. In the European and Mediterranean Plant Protection Organization region, MLAX and MFRG are reported as indigenous while MFRC and MPOL are invasive and have been introduced at the beginning of the new millennium. MFRC is regulated by European Union (EU) legislation whereas MPOL and the other Monilinia spp. are apparently not regulated. However, although host plants intended for planting can be imported in Europe only from countries where MFRC is absent, the pathogen is well established in several EU areas (EFSA Panel on Plant Health 2011).

In Italy, MLAX and MFRG were believed to be the exclusive causal agents of brown rot until 2009, when MFRC was first reported in northern Italy (Pellegrino et al. 2009) and later in central Italy (Martini et al. 2013). Afterward, MPOL was also reported in central Italy (Martini et al. 2014). To our knowledge, this is the first report of MFRC and MPOL in southern Italy. Results of the monitoring carried out mainly in 2014 show that MFRC is widespread in all of the sampled areas in southern Italy and, hence, it is obviously well adapted to the climatic conditions of the area. Indeed, MFRC was recently reported in other countries of the Mediterranean basin such as Spain, where it displaced MFRG, coexisting with MLAX at a similar frequency (Villarino et al. 2013). In Greece, only MFRC and MLAX are reported (Papavasileiou et al. 2015). The coexistence between MFRC and MLAX was previously reported in the United States, where the two species exploit somewhat different ecological niches at early or late stages in the season, although MFRC is the prevalent brown rot pathogen (Boehm et al. 2001). Our findings indicate that
MFRC is replacing both MLAX and MFRG on stone fruit in southern Italy. MFRC, indeed, was found in $81 \%$ of the sampled orchards and represented $75 \%$ of sampled isolates, while MLAX, representing $23 \%$ of isolates, was recovered in around $58 \%$ of orchards. MPOL and MFRG were found only in Basilicata in one and two sampled orchards, respectively, and together were around $2.5 \%$ of isolates.

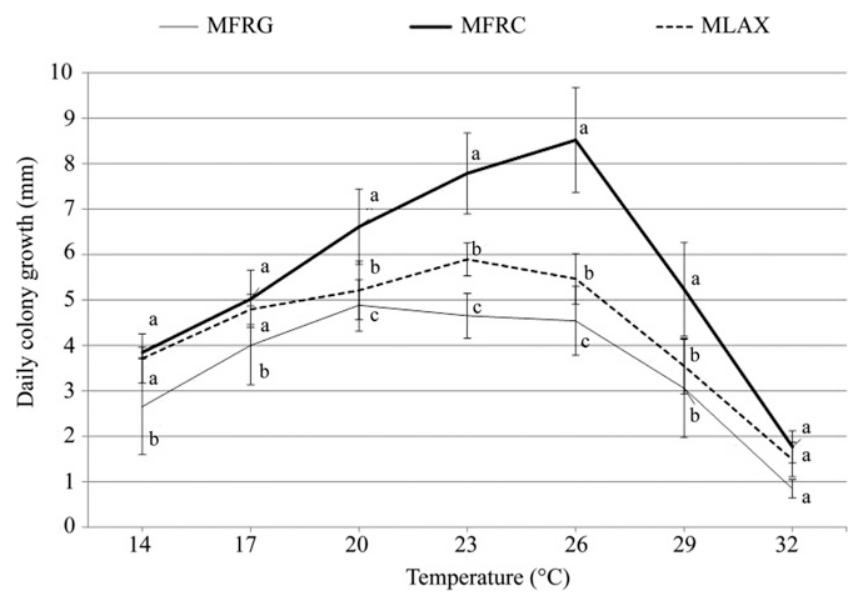

Fig. 4. Influence of temperature on the colony growth of the three Monilinia spp. MFRG $=$ Monilinia fructigena, MFRC $=M$. fructicola, and MLAX $=M$. laxa. Daily growth was calculated on the data recorded at 4 and 8 days after inoculation. Each point represents the mean values of five isolates and bars represent standard errors. Data followed by a same letter are not statistically different according to Tukey's test at probability level $P \leq 0.05$.

Table 6. Diameters (in millimeters) of rotting areas on fruit surface at 3 days after inoculation with Monilinia spp. ${ }^{\mathrm{z}}$

\begin{tabular}{lccc}
\hline Monilinia spp. & Apricot & Cherry & Peach \\
\hline Monilinia fructigena & $36.2 \mathrm{ab} \mathrm{A}$ & $4.5 \mathrm{a}$ & $42.7 \mathrm{a}$ \\
M. laxa & $36.4 \mathrm{a} A$ & $4.9 \mathrm{a}$ & $39.7 \mathrm{a}$ \\
M. fructicola & $33.0 \mathrm{~b} \mathrm{~A}$ & $2.3 \mathrm{a}$ & $36.8 \mathrm{a}$ \\
\hline
\end{tabular}

${ }^{\mathrm{z}}$ Data represent mean values of 10 replicated fruit. Data followed by the same letter are not statistically different according to Tukey's test at $P \leq 0.05$ probability level.

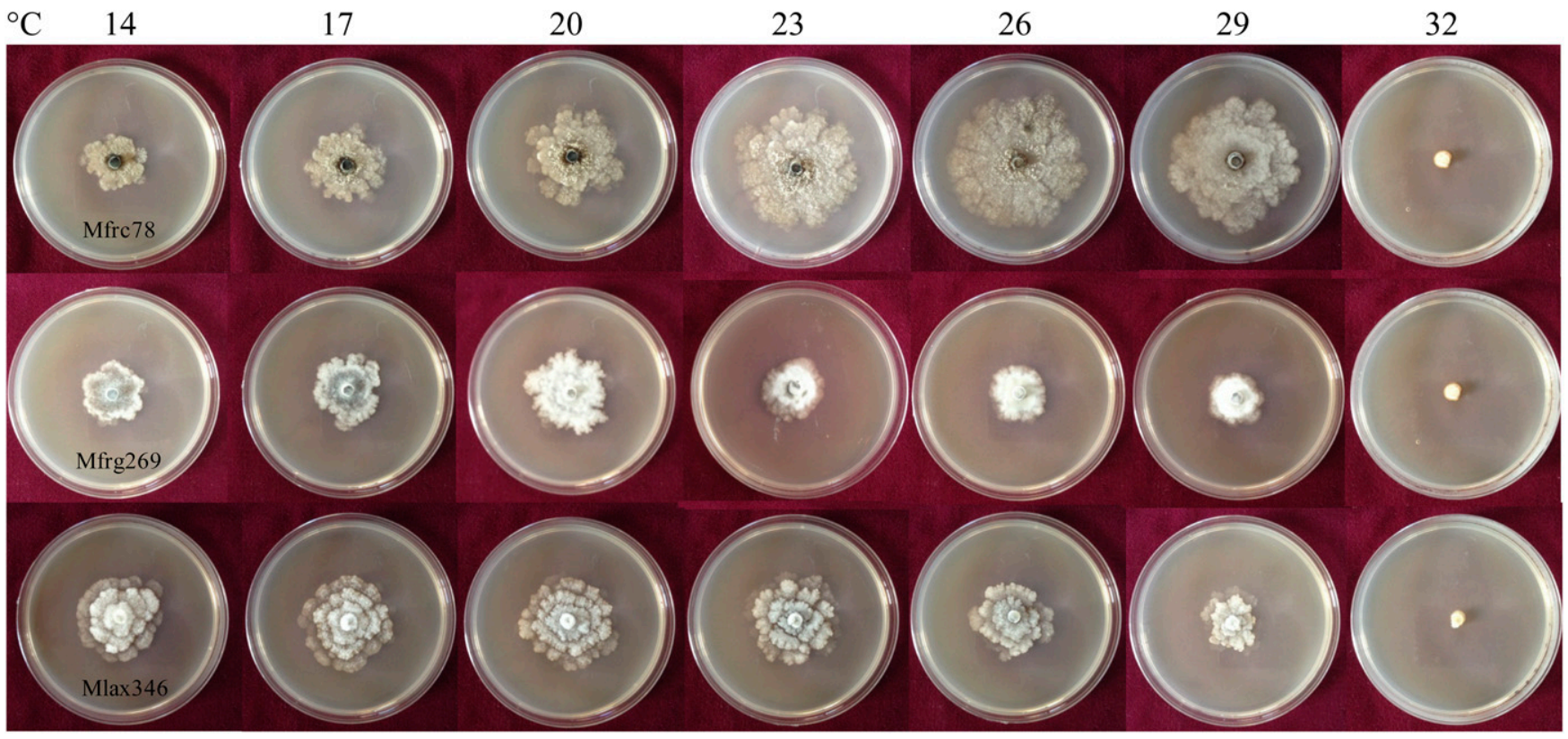

Fig. 3. Colony growth of reference strains of Monilinia fructicola (Mfrc78), M. fructigena (Mfrg269), and M. laxa (Mlax346) after 7 days of incubation at different temperatures. 
MFRC and MLAX coexist in 39\% of orchards, although on different fruit, and MFRC was the prevalent species. In 2014, the main year of monitoring, brown rot was more severe on cherry and peach than on plum and apricot. MFRC was always prevalent on all crops and this suggests that no differences occur in host susceptibility.

Distinguishing Monilinia spp. based on morphological characteristics is tedious and time consuming, and requires taxonomic expertise. Moreover, the identification of the brown rot pathogens is complicated because of their common hosts and phenological stages.
MLAX is mostly responsible for blossom and twig blights whereas MFRC is particularly aggressive on fruit (Michailides et al. 2007). Several PCR-based molecular tests have been developed to distinguish MFRC from the other Monilinia spp. (Boehm et al. 2001; Côté et al. 2004; Förster and Adaskaveg 2000; Gell et al. 2007; Hughes et al. 2000; Ioos and Frey 2000; Ma et al. 2003; Riccioni and Valente 2015; Zhu et al. 2016) and most of them were compared in a proficiency test finalized to identify the most suitable protocol (Riccioni and Valente 2015). Real-time PCR methods for MFRC quantification

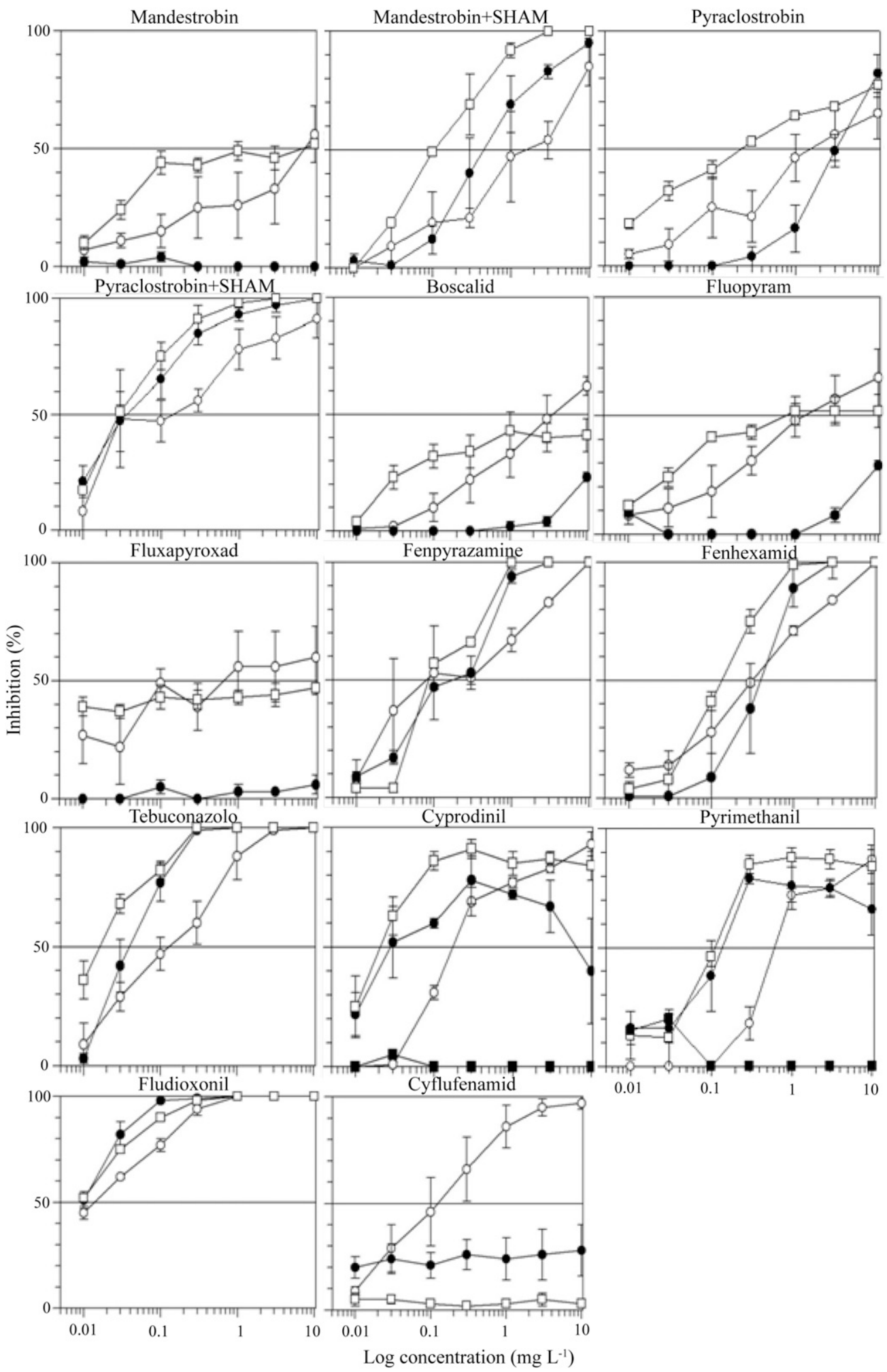

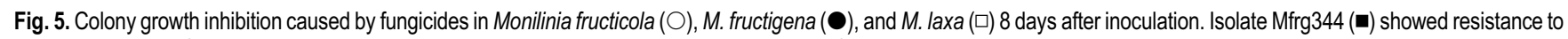
anilinopyrimidines. SHAM = salicylhydroxamic acid. Each point represents the mean value of three isolates and bars represent the standard error. 
have been also developed (Luo et al. 2007; Van Brouwershaven et al. 2010; Vilanova et al. 2017). Moreover, a one-step detection of MFRC, MFRG, and MLAX on fruit, twigs, and flowers of Prunus and Malus spp. was recently set up for improving the use of molecular tools in reliable massive analyses in the framework of official controls (Guinet et al. 2016). In our research, we lightly modified the method of Côté et al. (2004) and this allowed direct PCR from mycelium and conidia collected from rotted fruit or fungal cultures, thus avoiding the time- and labor-consuming stage of DNA extraction and purification. The method was validated and extensively used during the monitoring. At the same time, a specific and sensitive TaqMan-based qPCR was set up for the three species. The method appropriately quantified mixtures of conidia in different proportions of MFRC and MLAX, which are the prevalent brown rot pathogens in southern Italy, and was validated on field samples. Hence, additional new molecular tools are available for monitoring and research on Monilinia spp.

The rapid spreading of MFRC in Mediterranean countries suggests that the fungus has competitive advantages on MLAX and MFRG. This can be due to several factors such as a higher fitness in the hot and dry climate of the area or higher sporulation and virulence and, possibly, different response to fungicides more often used against brown rot. In this work, we compared the behavior of several isolates of each species to take into account the intraspecific variation among isolates (Pariaud et al. 2009; Vasić et al. 2018).

The influence of temperature on colony growth was evaluated in the range of 14 to $32^{\circ} \mathrm{C}$. MFRC (optimum at approximately $26^{\circ} \mathrm{C}$ ) proved to be more thermophilic than MLAX (optimum at approximately $23^{\circ} \mathrm{C}$ ) and MFRG (optimum at approximately $20^{\circ} \mathrm{C}$ ). Moreover, MFRC displayed faster colony growth (up to $3 \mathrm{~mm} \mathrm{day}^{-1}$ ) and more abundant sporulation (up to 100 times) than the other two species, especially at 17 to $26^{\circ} \mathrm{C}$. In preliminary tests, the virulence of the three species was evaluated through artificial inoculation on apricot, cherry, and peach fruit and no significant differences were generally recorded in our experimental conditions. The only exception was on apricot fruit, on which MFRC was less virulent than MLAX and MFRG. Our findings corroborate data previously reported by De Cal et al. (2014) on MLAX and MFRC and differ from those reported by Villarino et al. (2016), who observed higher virulence of MFRC as compared with MLAX and MFRG following artificial inoculation with conidia on wounded nectarine fruit. These differences can be attributed to different experimental conditions, and merit further investigation.

Crop management and sanitation practices are not enough to control brown rot adequately and fungicide sprays are often required. Numerous site-specific fungicides, including benzimidazoles, SBII, SBI-III, AP, PP, cyflufenamid, and respiration inhibitors such as QoI and SDHI, are used to control blossom blight and fruit rot. The baseline sensitivity of the three Monilinia spp. to several fungicides selected for their mode of action was investigated. QoI (mandestrobin and pyraclostrobin), SDHI (boscalid, fluopyram, and fluxapyroxad), SBI-I (tebuconazole), SBI-III (fenpyrazamine and fenhexamid), AP (cyprodinil and pyrimethanil), PP (fludioxonil), and cyflufenamid fungicides were used in the assays on the sensitivity of MFRC, MLAX, and MFRG. The QoI fungicides (mandestrobin and pyraclostrobin) were ineffective in inhibiting colony growth of MLAX, MFRC, and specially MFRG when tested alone in the MEA medium. The addition to MEA of SHAM, a specific inhibitor of cyanide-resistant alternative respiration, improved dramatically the inhibitor effects of both fungicides against all the three species. These findings suggest a high activity of alternative oxidases even in Monilinia, as in other members of Sclerotiniaceae (Ishii et al. 2009). Likely, the SDHI fungicides inhibited the colony growth more effectively in MRFC and MLAX than in MFRG. SBI-I, SBI-III, and fludioxonil were the most effective in controlling the three Monilinia spp. According to Malandrakis et al. (2013), tebuconazole, fenhexamid, and fenpyrazamine were more effective to inhibit MLAX mycelial growth. Fludioxonil was particularly effective in inhibiting mycelial growth of MFRC. As far as AP is concerned, cyprodinil and pyrimethanil moderately inhibited the colony growth of both
MFRC and MLAX and, even less (especially cyprodinil), that of MFRG. Moreover, the MRFG isolate Mfrg344, sampled in EmiliaRomagna (central Italy), where AP are commonly applied, was resistant to both AP fungicides. Generally, MLAX was more sensitive to fungicides than MFRC, with particular regard to fludioxonil. Strong differences in sensitivity to cyflufenamid among the three Monilinia spp. was observed; the fungicide was particularly effective in reducing colony growth of MFRC, in agreement with Haramoto et al. (2006), but was moderately effective against MLAX and even less against MFRG. These results should be considered in planning crop protection strategies in orchards, depending on the prevalent Monilinia spp. causing brown rot, and for following the possible evolution of acquired resistance to fungicides in fungal populations under the selective pressure exerted by chemical sprays. Indeed, most of the fungicides effective against Monilinia spp. have a specific mode of action and, hence, they are generally more effective than multisite fungicides but, on the other hand, are often at high risk of resistance. Indeed, resistance to fungicides with different modes of action has already occurred in MFRC and MLAX in different countries such as the United States (South Carolina and Georgia) and Spain (Chen et al. 2013; Egüen et al. 2016; Schnabel et al. 2004).

In conclusion, this is the first report of the quarantined MFRC and MPOL on stone fruit in southern Italy. We found that MFRC is more thermophilic, grew faster, and sporulated more abundantly than MLAX and MFRG. However, we could not observe differences in aggressiveness on artificially inoculated stone fruit. These observations may partially explain the high fitness of MFRC in southern Italy, where the pathogen is displacing MLAX and MFRG. The three pathogens show differential responses to the fungicides commonly used against brown rot. Therefore, assessing the prevalence of Monilinia spp. present in orchards is necessary to develop disease management strategies.

\section{Acknowledgments}

We thank F. Nigro of our department and M. Mari (Department of Agricultural Sciences, University of Bologna, Italy) for providing us with fungal isolates; and C. Dongiovanni, M. Dicarolo, and G. Fumarola (Centro di Ricerca, Formazione e Sperimentazione in Agricoltura "Basile Caramia", Locorotondo [BA], M. Pizzi (Sumitomo Chemicals, Italy), L. Catalano (Agrimeca Grape and Fruit Consulting, Turi [BA], Italy), and all technicians and growers involved in the monitoring program for their cooperation.

\section{Literature Cited}

Beadle, G. W., and Tatum, E. L. 1945. Neurospora. II. Methods of producing and detecting mutations concerned with nutritional requirements. Am. J. Bot. 32: 678-686.

Boehm, E. W. A., Ma, Z., and Michailides, T. J. 2001. Species-specific detection of Monilinia fructicola from California stone fruits and flowers. Phytopathology 91:428-439.

Bustin, S. A., Benes, V., Garson, J. A., Hellemans, J., Huggett, J., Kubista, M., Mueller, R., Nolan, T., Pfaffl, M. W., Shipley, G. L., Vandesompele, J., and Wittwer, C. T. 2009. The MIQE guidelines: Minimum information for publication of quantitative real-time PCR experiments. Clin. Chem. 55:611-622.

Byrde, R. J. W., and Willetts, H. J. 1977. The Brown Rot Fungi of Fruit-Their Biology and Control. Pergamon Press, New York.

Chen, F., Liu, X., Chen, S., Schnabel, E., and Schnabel, G. 2013. Characterization of Monilinia fructicola strains resistant to both propiconazole and boscalid. Plant Dis. 97:645-651.

Côté, M. J., Tardif, M. C., and Meldrum, A. J. 2004. Identification of Monilinia fructigena, M. fructicola, M. laxa, and Monilia polystroma on inoculated and naturally infected fruit using multiplex PCR. Plant Dis. 88:1219-1225.

De Cal, A., Egüen, B., and Melgarejo, P. 2014. Vegetative compatibility groups and sexual reproduction among Spanish Monilinia fructicola isolates obtained from peach and nectarine orchards, but not Monilinia laxa. Fungal Biol. 118:484-494.

De Miccolis Angelini, R. M., Habib, W., Rotolo, C., Pollastro, S., and Faretra, F. 2010. Selection, characterization and genetic analysis of laboratory mutants of Botryotinia fuckeliana (Botrytis cinerea) resistant to the fungicide boscalid. Eur. J. Plant Pathol. 128:185-199.

EFSA Panel on Plant Health. 2011. Pest risk assessment of Monilinia fructicola for the EU territory and identification and evaluation of risk management options. EFSA J. 9:2119.

Egüen, B., Melgarejo, P., and De Cal, A. 2016. The effect of fungicide resistance on the structure of Monilinia laxa populations in Spanish peach and nectarine orchards. Eur. J. Plant Pathol. 145:815-827. 
Förster, H., and Adaskaveg, J. E. 2000. Early brown rot infections in sweet cherry fruit are detected by Monilinia-specific DNA primers. Phytopathology 90: $171-178$.

Gell, I., Cubero, J., and Melgajero, P. 2007. Two different approaches for universal diagnosis of brown rot and identification of Monilinia spp. in stone fruit trees. J. Appl. Microbiol. 103:2629-2637.

Guinet, C., Fourrier-Jeandel, C., Cerf-Wendling, I., and Ioos, R. 2016. One-step detection of Monilinia fructicola, M. fructigena, and M. laxa on Prunus and Malus by a multiplex real-time PCR assay. Plant Dis. 100:2465-2474.

Harada, Y., Nakao, S., Sasaki, M., Sasaki, Y., Ichihashi, Y., and Sano, T. 2004. Monilia mumecola, a new brown rot fungus on Prunus mume in Japan. J. Gen. Plant Pathol. 70:297-307.

Haramoto, M., Yamanaka, H., Hosokawa, H., Sano, H., Sano, S., and Otani, H. 2006. Control efficacy of cyflufenamid in the field and its fungicidal properties. J. Pestic. Sci. 31:116-122.

Hu, M. J., Cox, K. D., Schnabel, G., and Luo, C. X. 2011. Monilinia species causing brown rot of peach in China. PLoS One 6:e24990.

Hughes, K. J. D., Fulton, C. E., McReynold, D., and Lane, C. R. 2000. Development of new PCR primers for identification of Monilinia species. Bull. OEPP 30:507-511.

Ioos, R., and Frey, P. 2000. Genomic variation within Monilinia laxa, M. fructigena and $M$. fructicola, and application to species identification by PCR. Eur. J. Plant Pathol. 106:373-378.

Ishii, H., Fountaine, J., Chung, W. H., Kansako, M., Nishimura, K., Takahashi, K., and Oshima, M. 2009. Characterisation of QoI-resistant field isolates of Botrytis cinerea from citrus and strawberry. Pest Manage. Sci. 65:916-922.

Lane, C. R. 2002. A synoptic key for differentiation of Monilinia fructicola, $M$. fructigena and $M$. laxa, based on examination of cultural characters. Bull. OEPP 32:489-493.

Luo, Y., Ma, Z., Reyes, H. C., Morgan, D., and Michailides, T. J. 2007. Quantification of airborne spores of Monilinia fructicola in stone fruit orchards of California using real-time PCR. Eur. J. Plant Pathol. 118:145-154.

Ma, Z., Luo, Y., and Michailides, T. J. 2003. Nested PCR assays for detection of Monilinia fructicola in stone fruit orchards and Botryosphaeria dothidea from pistachios in California. J. Phytopathol. 151:312-322.

Malandrakis, A., Koukiasas, N., Veloukas, T., Karaoglanidis, G., and Markoglou, A. 2013. Baseline sensitivity of Monilinia laxa from Greece to fenhexamid and analysis of fenhexamid-resistant mutants. Crop Prot. 46:13-17.

Martini, C., Lantos, A., Di Francesco, A., Guidarelli, M., D’Aquino, S., and Baraldi, E. 2014. First report of Asiatic brown rot caused by Monilinia polystroma on Peach in Italy. Plant Dis. 98:1585.

Martini, C., Spadoni, A., and Mari, M. 2013. First report of brown rot caused by Monilinia fructicola on apple in Italy. Plant Dis. 97:689.

Michailides, T., Luo, Y., Ma, Z., and Morgan, D. P. 2007. Brown rot of dried plum in California: New insights on an old disease. Online publication. APSnet Features. http://www.apsnet.org/publications/apsnetfeatures/Pages/BrownRot. aspx
Mordue, J. E. M. 1979a. Sclerotinia fructicola. CMI Descriptions of Pathogenic Fungi and Bacteria No. 616. CAB International, Wallingford, UK.

Mordue, J. E. M. 1979b. Sclerotinia fructigena. CMI Descriptions of Pathogenic Fungi and Bacteria No. 617. CAB International, Wallingford, UK.

Mordue, J. E. M. 1979c. Sclerotinia laxa. CMI Descriptions of Pathogenic Fungi and Bacteria No. 619. CAB International, Wallingford, UK.

OEPP/EPPO. 2002. First report of Monilinia fructicola in France. EPPO Reporting Service no. 01-2002. Article 2002/003. Online publication. EPPO Global Database. https://gd.eppo.int/reporting/article-2166

OEPP/EPPO. 2009. PM 7/18 (2): Monilinia fructicola. Bull. OEPP/EPPO Bull. 39: 337-343.

Papavasileiou, A., Testempasis, S., Michailides, T. J., and Karaoglanidis, G. S. 2015. Frequency of brown rot fungi on blossoms and fruit in stone fruit orchards in Greece. Plant Pathol. 64:416-424.

Pariaud, B., Ravigné, V., Halkett, F., Goyeau, H., Carlier, J., and Lannou, C. 2009 Aggressiveness and its role in the adaptation of plant pathogens. Plant Pathol. 58:409-424.

Pellegrino, C., Gullino, M. L., Garibaldi, A., and Spadaro, D. 2009. First report of brown rot of stone fruit caused by Monilinia fructicola in Italy. Plant Dis. 93:668

Riccioni, L., and Valente, M. T. 2015. Comparison of different PCR tests to identify Monilinia fructicola. Bull. OEPP 45:33-40.

Sanderson, K. E., and Srb, A. M. 1965. Heterokaryosis and parasexuality in the fungus Ascochyta imperfecta. Am. J. Bot. 52:72-81.

Schnabel, G., Bryson, P. K., Bridges, W. C., and Brannen, P. M. 2004. Reduced sensitivity in Monilinia fructicola to propiconazole in Georgia and implications for disease management. Plant Dis. 88:1000-1004.

Van Brouwershaven, I. R., Bruil, M. L., Van Leeuwen, G. C. M., and Kox, L. F. F. 2010. A real-time (TaqMan) PCR assay to differentiate Monilinia fructicola from other brown rot fungi of fruit crops. Plant Pathol. 59:548-555.

Van Leeuwen, G. C., Baayen, R. P., Holb, I. J., and Jeger, M. J. 2002. Distinction of the Asiatic brown rot fungus Monilia polystroma sp. nov. from M. fructigena. Mycol. Res. 106:444-451.

Vasić, M., Vico, I., Jurick, W., II, and Duduk, N. 2018. Distribution and characterization of Monilinia spp. causing apple fruit decay in Serbia. Plant Dis. 102:359-369.

Vilanova, L., Usall, J., Teixidó, N., and Torres, R. 2017. Assessment of viable conidia of Monilinia fructicola in flower and stone fruit combining propidium monoazide (PMA) and qPCR. Plant Pathol. 66:1276-1287.

Villarino, M., Egüen, B., Lamarca, N., Segarra, J., Usall, J., Melgarejo, P., and De Cal, A. 2013. Occurrence of Monilinia laxa and M. fructigena after introduction of $M$. fructicola in peach orchards in Spain. Eur. J. Plant Pathol. 137:835-845.

Villarino, M., Melgarejo, P., and De Cal, A. 2016. Growth and aggressiveness factors affecting Monilinia spp. survival peaches. Int. J. Food Microbiol. 224:22-27.

Zhu, X.-Q., Niu, C.-W., Chen, X.-Y., and Guo, L.-Y. 2016. Monilinia Species Associated with Brown Rot of Cultivated Apple and Pear Fruit in China. Plant Dis. 100:2240-2250. 